(ref. 3), the entire lake margin is surrounded by toxic scum and it is not possible to wade out to open water without passing through the scum. Animal poisonings due to the ingestion of toxic planktonic cyanobacterial scum, or concentrated bloom, seem to occur as unavoidable consequences of contact with toxic planktonic scums and blooms. The habit that dogs have of licking adherent material from their coats has contributed to the ingestion of lethal doses of hepatotoxic Nodularia spumigena after swimming in water containing scum ${ }^{4}$. Whether the dogs or livestock were attracted to the planktonic cyanobacteria is unknown.

We have investigated dog poisonings that have occurred rapidly after ingestion of neurotoxic benthic cyanobacteria accumulated along the margins of Scottish lochs in 1990, 1991 (ref. 5) and in May and June this year. The most recent neurotoxicoses at lochs Awe and Avich (Argyll) have included two deaths and two cases in which the animals eventually recovered. As before, we have identified benthic Oscillatoria spp. and the cyanobacterial neurotoxin anatoxin-a in scums and dog stomach contents. When visiting the sites where the poisonings occurred, we found that the accumulations of toxic cyanobacteria were highly localized. For example, at Loch Awe the deposits extended along the shore for about $10 \mathrm{~m}$, no more being encountered for more than $100 \mathrm{~m}$. Why then did the poisonings occur when the animals had ready access to clear water for drinking and swimming?

The dogs at lochs Awe and Avich were accompanied by their owners, who saw the animals eat from the shoreline deposits of toxic cyanobacteria. These deposits partly occurred as slime and wet mats in the shallows and partly as dried crusts above the waterline, which had fallen during dry weather. Scavenging by dogs is not in itself unusual, and we believe that this habit contributed to the location and ingestion of toxic doses of cyanobacterial neurotoxin. Why dogs should be attracted to toxic benthic cyanobacterial mats or crusts is unknown. Cyanobacteria, and other aquatic and terrestrial microbes such as actinomycetes, produce many taste and odour compounds which have hitherto been of interest due to their adverse impact on aquaculture and drinking water quality ${ }^{6}$. Perhaps these are attrac-

1. Francis, G. Nature 18, 11-12 (1878).

2. Carmichael, W. W. in Naturat Toxins: Characterization, Pharmacology and Therapeutics (eds Ownby, C. \& Odell, G. V.) 3-16 (Pergamon, Oxford, 1989)

3. Codd, G. A. \& Beattie, K. A. PHLS Microbiol. Digest 8 , 82-86 (1991)

4. Edler, L., Ferno, S., Lind, M. G., Lundberg, R. \& Nilsson, P. O. Ophelia 24, 103-109 (1985).

5. Gunn, G. J. et al. Vet. Rec. 130, 301-302 (1992).

6. Persson, P-E., Whitfield, F. B. \& Krasner, S. W. (eds) Wat. Sci. Technol. 25(2), 1-343 (1991). tive to opportunistic omnivores such as the domestic dog. The significance of cyanobacterial taste and odour compounds as (fatal) attractants to animals has yet to be investigated.

G. A. Codd

C. Edwards

K. A. Beattie

Department of Biological Sciences, University of Dundee,

Dundee DD1 $4 \mathrm{HN}$, UK

W. M. Barr

Duisdale,

Lochgilphead,

Argyll PA31 8NJ, UK

G. J. Gunn

Scottish Agricultural College,

Veterinary Investigation Centre,

Inverness IV2 4JZ, UK

\section{Dating of Nazca aqueducts}

SIR - It is true that, to the best of our present knowledge, Spanish colonial documents do not settle the question of the ultimate origin of the underground aqueducts (puquios) of Nazca ${ }^{1}$. However, at least one document does refer "specifically to the Nazca galleries". This is housed in Peru's national archive, and is part of the records of the viceregal water court ${ }^{2}$. It establishes and confirms the water distribution of the Visambra puquio from 1692 to 1778 , incorporating papers from the 1730 s. In 1698 several haciendas, a rectory and the Indian community of Nazca had to give up flow for two hours every morning so that water could pass through the town of Nazca.

What has been dated by atomic mass spectroscopy (AMS) is not necessarily the construction of the puquios, or the time the two stones sampled were placed in the canals, but rather the times when the stones were last trimmed by masons. In prehispanic, colonial and republican Andean architecture, the reuse of ancient dressed stone is very common. New vertical segments of the Cantalloq puquio have been constructed in living memory ${ }^{3}$ and it is worrying that Dorn et al. do not pinpoint the locations where their samples were taken ${ }^{4}$.

In 1954, archaeologists observed that the Nazca to Inca site of Tambo Viejo in the nearby Acarí valley was being disassembled and its stones trucked away for use in an unidentified irrigation project $^{5}$. Water flowed through this site, so the reuse of stones from Tambo Viejo would not be incompatible with the observation reported, but not illustrated, by Dorn et al., that the morphology of puquio varnish indicates that it formed in moist conditions. This is only circumstantial evidence, but it is enough to caution us that, as Bray writes', the matter of puquio dating is only "partially resolved".

As yet, a complete and accurate map of the Nazca puquios has not been published. Furthermore, large portions of the puquios consist of trenches dug a few metres to the water table, roofed with wood or stone lintels supporting earthern or rubble fill to ground level. It is these stone lintels that produced the AMS dates. To the best of my knowledge, no puquio has ever been excavated. A careful and extensive examination of fill contents might reveal much about the sequencing of puquio construction, a process that could not have been accomplished in a single moment. It is strange that archaeologists have not applied their most basic and characteristic methodology to the problems presented by the underground aqueducts of Nazca.

\section{Monica Barnes}

377 Rector Place,

Apartment 11,

New York, New York 10280, USA

1. Bray, W. Nature 358, 19 (1992)

2. Archivo General de la Nacion [Peru], Sección Colonial, Juzgado de Aguas 3.3.7.23 (1778) (cited in Barnes, M. \& Fleming, D. Latin American Antiquity 2, 48-68; 1991).

3. Schreiber, K. Lancho Rojas, J. Bolétin de Lima 59. 51-62 (1988)

4. Dorn, R. I., Clarkson, P.B., Nobbs, M.F., Loendorf, L. L. \& Whitley, D. S. Ann. Ass. Am. Geogr. 82, 136-151 (1992)

5. Menzel, D. \& Riddell, F. A. Archaeological Investigations at Tambo Viejo Acari Valley, Peru 1954 (California Institute for Peruvian Studies, 1986).

\section{Geomagnetic reversal paths}

SIR - Valet et al. ${ }^{1}$ concluded that there is no statistical evidence for a preferred sector of longitude in the distribution of mean virtual geomagnetic pole (VGP) paths during reversals. This contradicts the earlier suggestion that the transitional field VGPs have a tendency to follow the longitudinal band over the Americas and to a lesser extent its antipode ${ }^{2}$, an idea which we have used to infer aspects of core-mantle dynamics ${ }^{3}$. We believe that the statistical analysis of Valet et al. has led them to an incorrect conclusion.

The criteria used by the authors of both studies ${ }^{1,3}$ to select reliable records of reversals are basically the same: publication in refereed journals, existence of a reasonable number of transitional directions (usually 4 or 5), and sufficient description of the laboratory methods so that at least an idea of the magnetic cleaning is obtained. Thus there are only limited differences in the database of the two groups. These concern mainly the acceptance $^{2}$ or rejection ${ }^{1}$ of four records from Argentina now published in a refereed journal ${ }^{4}$ and, more important, of 